\title{
Polymagmatic Processes at Monogenetic Volcanoes: Insights from Baossi Monogenetic Lava Flows, Adamawa Plateau, Cameroon Volcanic Line
}

\author{
Anicet Feudjio Tiabou ${ }^{1,2}$, Robert Temdjim ${ }^{2}$, Caroline Neh Ngwa ${ }^{1,3}$, Vivian Bih Che ${ }^{1} \&$ François Xavier Onana \\ Mebara $^{2,3}$ \\ ${ }^{1}$ Remote Sensing Unit, Department of Geology, University of Buea, Cameroon \\ ${ }^{2}$ Department of Earth Sciences, University of Yaounde 1, Cameroon \\ ${ }^{3}$ Institute for Mining and Geological Research (IRGM), Cameroon \\ Correspondence: Anicet Feudjio Tiabou, Department of Geology, University of Buea, P.O. Box 63, Buea, South \\ West Region, Cameroon. Tel: 2376-7744-5106. E-mail: tiaboufa@yahoo.fr
}

Received: March 17, 2015

Accepted: April 7, 2015

Online Published: April 26, 2015

doi: $10.5539 /$ jgg.v7n2p56

URL: http://dx.doi.org/10.5539/jgg.v7n2p56

\begin{abstract}
This paper presents principally the textural and geothermometric evidence of polymagmatic activity at a monogenetic volcano along the Cameroon Volcanic Line $(\mathrm{CVL})$ in a bid to contribute to the global understanding of how such volume-limited basaltic magmatic systems operate. Preliminary geochemical data presented show that the lavas are alkali basalt and basanite $\left(\mathrm{SiO}_{2}: 40.42-47.59 \mathrm{wt} \%, \mathrm{MgO}: 7.61-9.13 \mathrm{wt} \%\right)$ and are petrographically indistinguishable. They outcrop as low mounds of columnar basalts associated with sparse pyroclastic materials. The lavas are fine, porphyritic with phenocrysts of olivine and clinopyroxene set in a plagioclase microlite-dominated hypocrystalline groundmass. Olivine has two distinct populations: grains that are anhedral to glomerocrystic with spinel and plagioclase inclusions and usually have resorbed margins (olivine 1); and grains that are euhedral, sometimes skeletal, with a thin and well preserved rim (olivine 2). Similarly two clinopyroxene crystal populations are recognizable: clinopyroxene grains that are resorbed, dismembered, with sieve-textured cores and irregular core-rim margins (clinopyroxene 1); and euhedral clinopyroxene grains partially enclosing olivine phenocrysts with sector and hour glass shape zoning (clinopyroxene 2). These textural features suggest that the eruption was caused by an influx of a fresh batch of magma (that crystallized olivine 2 and clinopyroxene 2) into a fractionated crystal mush (olivine 1 and clinopyroxene 1 ) in the chamber. The crystal mush was re-heated by the intruding basaltic magma resulting in a broad pre-eruption liquidus temperature of $1040-1156^{\circ} \mathrm{C}$ calculated using mineral chemistry of equilibrium olivine-clinopyroxene pairs.
\end{abstract}

Keywords: Cameroon volcanic line, geothermometry, monogenetic volcano, olivine-clinopyroxene pairs

\section{Introduction}

Monogenetic volcanoes are very widespread in continental basaltic volcanic provinces and they were once thought of as simple volcanic edifices resulting from less complicated magmatic processes (e.g., Boyce et al. 2015 and references therein). However, increasing body of knowledge exists now challenging this paradigm and has demonstrated a wide spectrum of polymagmatic processes that occur at such monogenetic centres. A monogenetic volcano is one with restricted magma supply such that once erupted, subsequent magma batches can no longer exit through the same path (Walker, 2000) and thus represent one shortlived phase of eruption (Boyce et al., 2015). However geochemical and textural data now suggest that various mechanisms exist defining the functioning of polymagmatic processes at monogenetic volcanoes (see Brenna et al., 2010, 2011, 2012 for details). Within magma chambers at such centres different pulses or batches of magma can mix resulting in complex evolutionary trends and different textural features, yet eventually erupt during a single event. For example, three magma batches have been identified at Jeju, South Korea (Sohn et al., 2012) while sequential eruption of alkaline and sub-alkaline magmas have been studied at monogenetic volcanoes in New Zealand (Needham et al., 2011). These studies have emphasized the need for further investigation of monogenetic volcanoes and this study is aimed at contributing to this theme.

The Cameroon Volcanic Line (CVL) is an intraplate megastructure that stretches from the Islands of the Atlantic 
Ocean off the coast of west Africa into the heart of the continent (Figure 1). Although several volcanoes along this chain have been investigated at various times addressing various themes, monogenetic eruptions have received relatively little attention especially in the northern end of the CVL. Here we present textural and preliminary geochemical data to show that the small monogenetic centres in Ngaoundere, Adamawa Plateau along the CVL present complex polymagmatic features that could be of relevance to better understanding magma plumbing and conduit processes at even the larger edifices of the CVL.

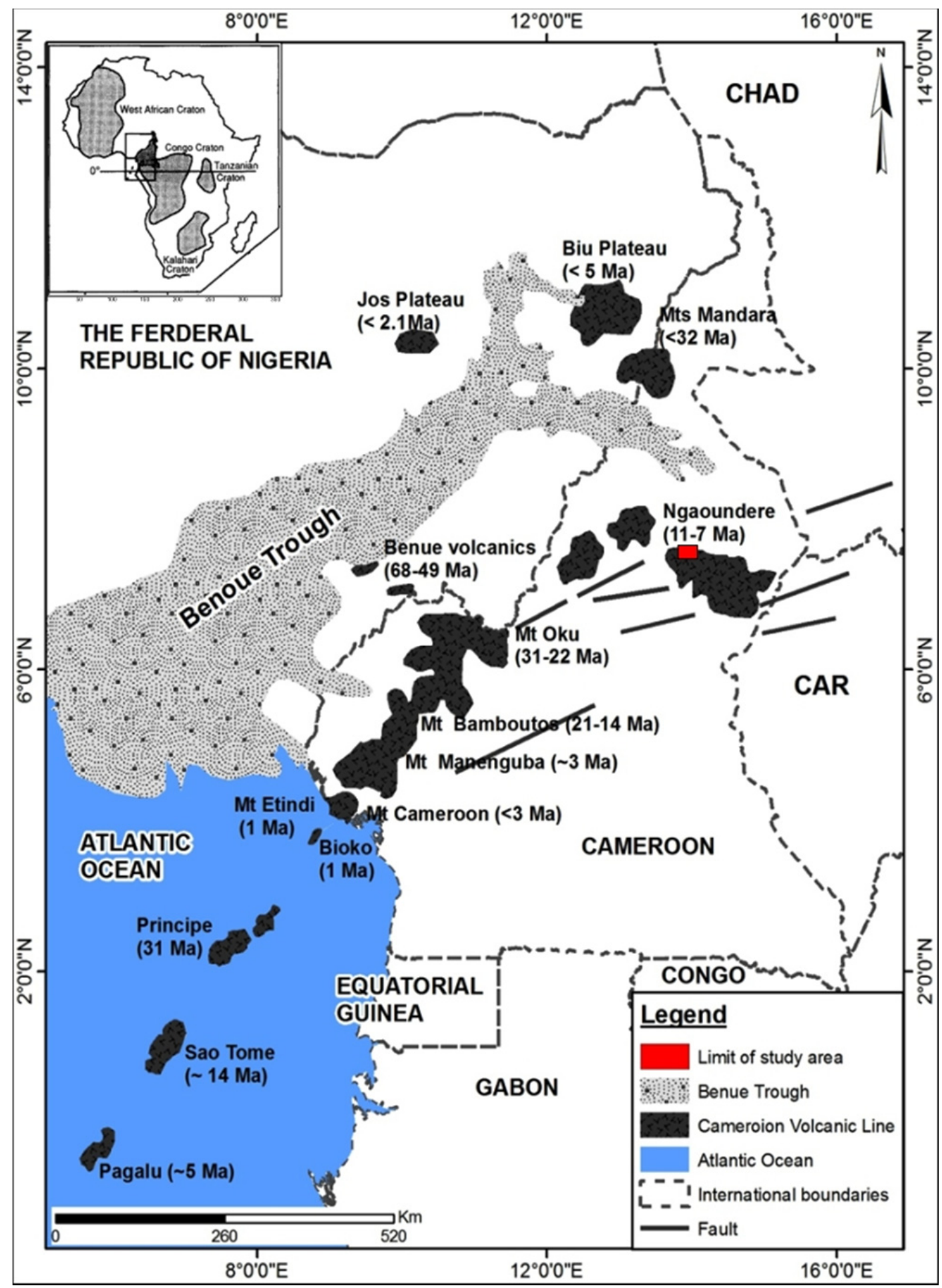

Figure 1. Structural disposition of the Cameroon Volcanic Line (CVL) with ages of the principal volcanic centres (after Marzoli et al., 1999) indicated. The study area with the Baossi cones is part of the Adamawa complex around Ngaoundere 


\section{Geological Setting}

The CVL is a spectacular feature whose origin has defied most plate tectonic and structural models. This Yshaped system (Figure 1) has a long history of magmatic activity, both plutonic and volcanic, spanning over $\sim 70$ Ma and basaltic flows that mark the onset of volcanism along the line are recognisable in the Adamawa Plateau (Déruelle et al., 2007) even though activity at this end remained high until $\sim 5 \mathrm{Ma}$ (Grant et al., 1972). Volcanic rocks of the CVL range in age from $\sim 32$ Ma to Recent considering that Mt Cameroon at the southern end of the line is still active. The anorogenic plutonic massifs are much older and bracket $\sim 65$ to $70 \mathrm{Ma}$ (see data compiled in Montigny et al., 2004). In both the oceanic and continental segments of the CVL, volcanic activity has lasted for over $30 \mathrm{Ma}$ and this is not directly linked to any plate motion suggesting that the mantle swells that supply magma to the CVL volcanoes must be attached to the continent (Milelli et al., 2011). This is supported by regional gravity data and residual Bouguer anomaly maps that show that magmatism along the CVL has little effect on its crustal structure such as crustal thinning (Tokam et al., 2010) and the thickness of the mantle transition zone (Reusch et al., 2011).

Helium isotope signatures of CVL magmas do not confirm to a hot spot related origin (Aka et al., 2004) and this is supported by the absence of any systematic age progression along the CVL (Montigny et al., 2004). The parental melts of CVL magmas are predominantly alkali basalts with restricted tholeiitic compositions (Kamgang et al., 2007; Teitchou et al., 2011). The isotopic signatures of lavas from both the continental and oceanic volcanoes show no clear distinction (Rankenburg et al., 2005) and they are linked to asthenospheric, enriched sub-continental lithospheric mantle and continental crust sources (Déruelle et al., 2007). Mount Cameroon close to the ocean-continent boundary is still an active volcano with recent eruptions in 1999 and 2000 (Suh et al., 2003).

In the Adamawa area, K-Ar age determinations show that the volcanic activity occurred in two distinctive episodes 11-7 Ma and $<1 \mathrm{Ma}$. There is no evidence for volcanic activity between 7 and $1 \mathrm{Ma}$ (Nkouandou et al., 2008; Temdjim et al., 2004). Basaltic lava flows, scoria cones and trachy-phonolitic plugs have been mapped (Temdjim et al., 2003) and some bearing ultramafic xenoliths from the mantle (Temdjim et al., 2010; Nkouandou \& Temdjim, 2011). Hydro-magmatic explosive activities creating abundant cinder cones and maars are also known (Temdjim et al., 2006) and the diversity of volcanic edifices and pyroclastic deposits implies effusive and explosive eruptive styles at play. However how these relate to specific monogenetic volcanoes in the Adamawa plateau has not been investigated. This is the principal objective of this contribution.

\section{Sampling and Analytical Method}

The basaltic lavas of the Baossi area were carefully mapped and their principal field characteristics noted. Suitable samples were collected for subsequent petrographic and geochemical analyses taking stratigraphic positions into consideration. Polished thin sections were examined under both transmitted light microscope for pertinent textural features and under the scanning electron microscope for subtle features. Olivine and clinopyroxene pairs were analyzed under the electron microprobe following the analytical protocol discussed in Suh et al. (2008). The electron microprobe data were eventually used to calculate liquidus temperatures based on the geothermometric method of Loucks (1996). This geothermometer is particularly suitable for these samples considering that they are fresh and the phenocryst population is dominated by these phases.

For whole geochemical analysis, representative samples were crushed and pulverized and subsequently analysed by XRF and ICP-MS following methods outlined in Ngwa (2010).

\section{Results and Interpretations}

Morphologically the volcanic cones mapped are generally lowlying (angle of repose $\sim 33^{\circ}$ ) and 0.5 to $1.5 \mathrm{~km}$ in diameter. They are breached by lava flows and are asymmetrical (Warack) to symmetrical in shape (Baossi 1 and Baossi 2) and entirely covered with blocky and isolated or jointed columnar basalt flows (Figure 2 and 3). They are considered as monogenetic cones, formed by extrusion of magma through vents onto the granitic basement. These are volume-limited flows with lengths rarely exceeding a few tens of metres from the vent. The eruption sequence comprises successive layers of basaltic flows sometimes interspersed with tephra. However there are no paleosols or weathering boundaries separating these units. 


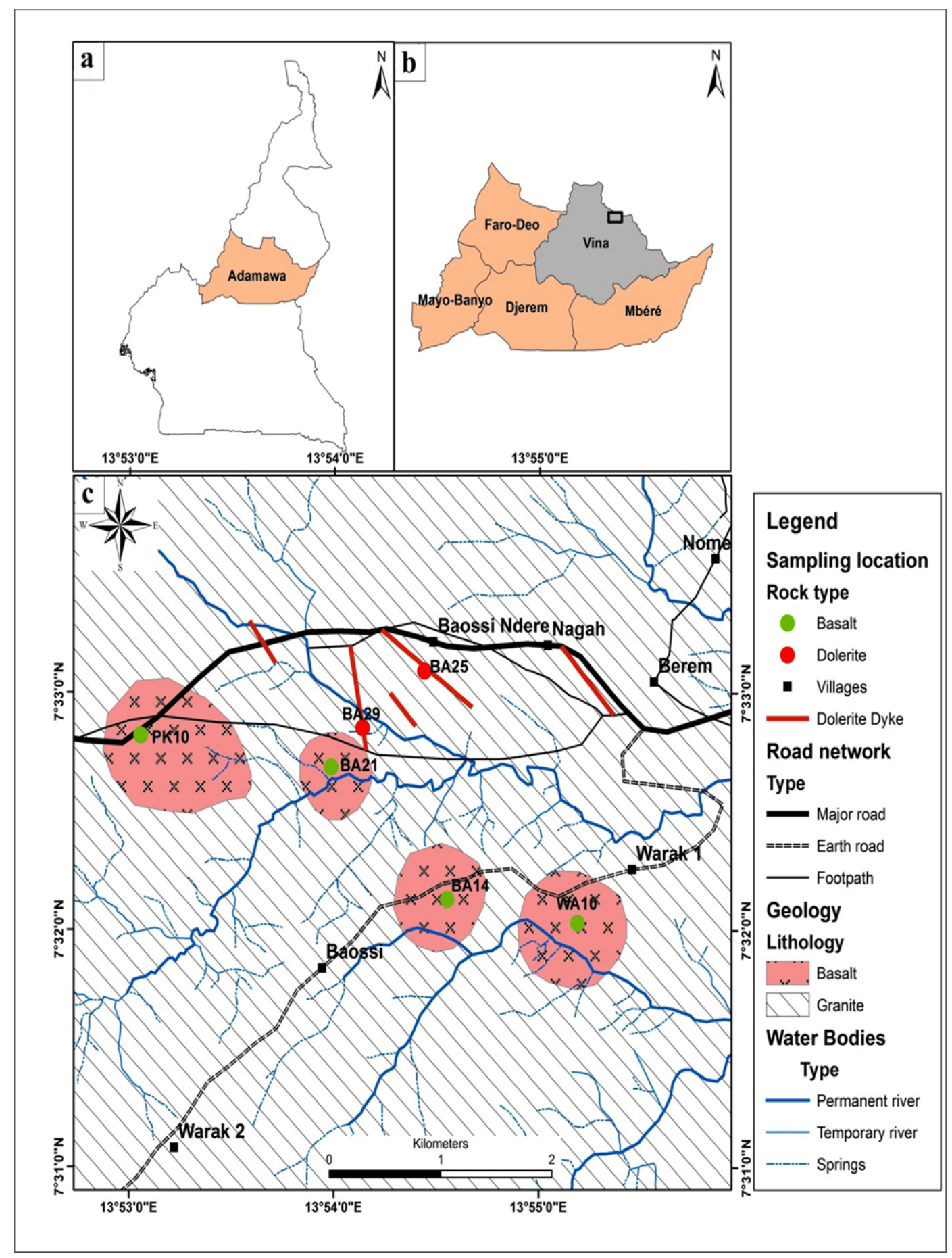

Figure 2. (a) Map of Cameroon with the Adamawa region (b). (c) Geologic map of the Baossi-Warack area. Sampling sites are indicated within the wider volcanic complex and situated at the site of the monogenetic cones 

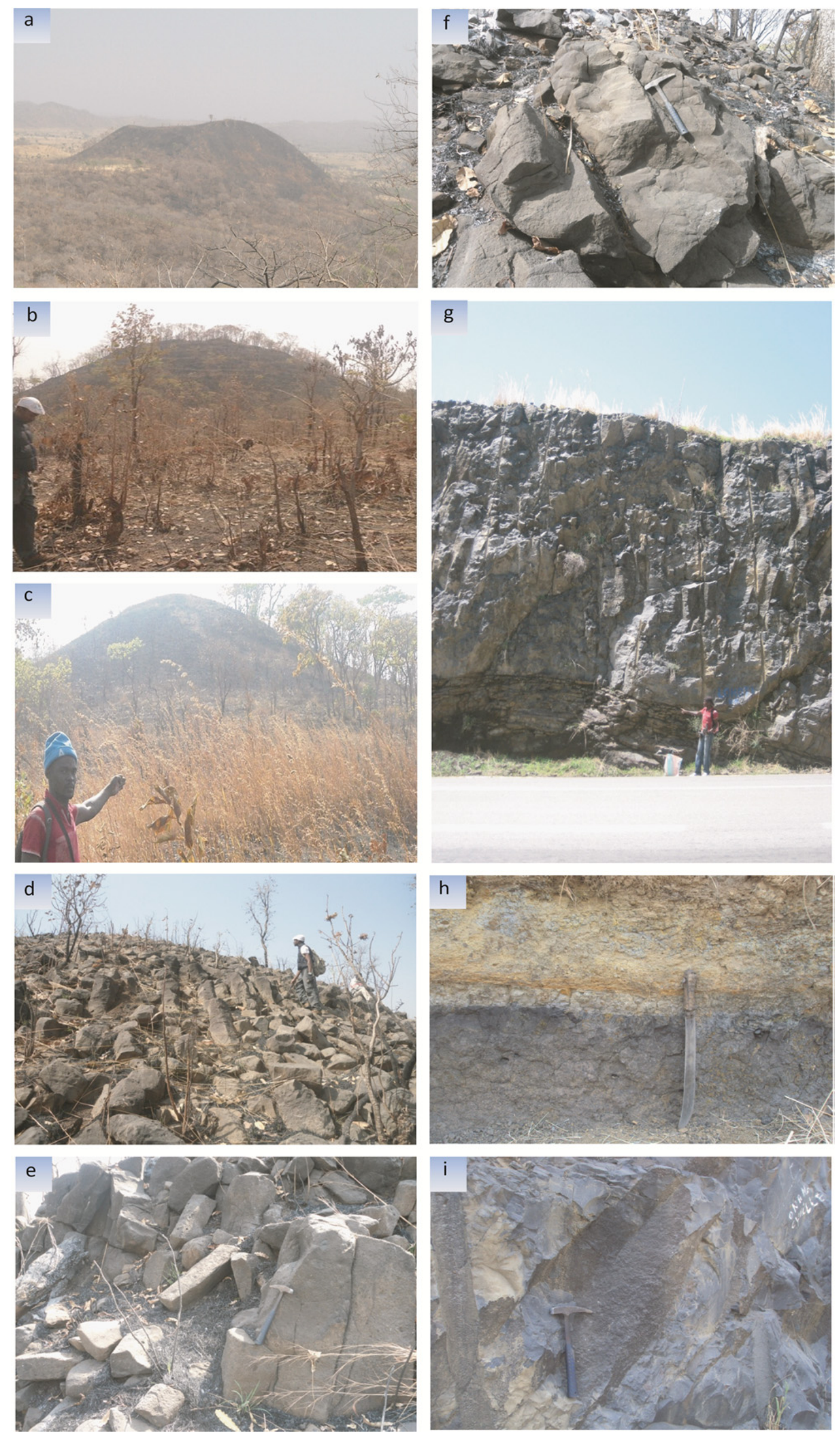

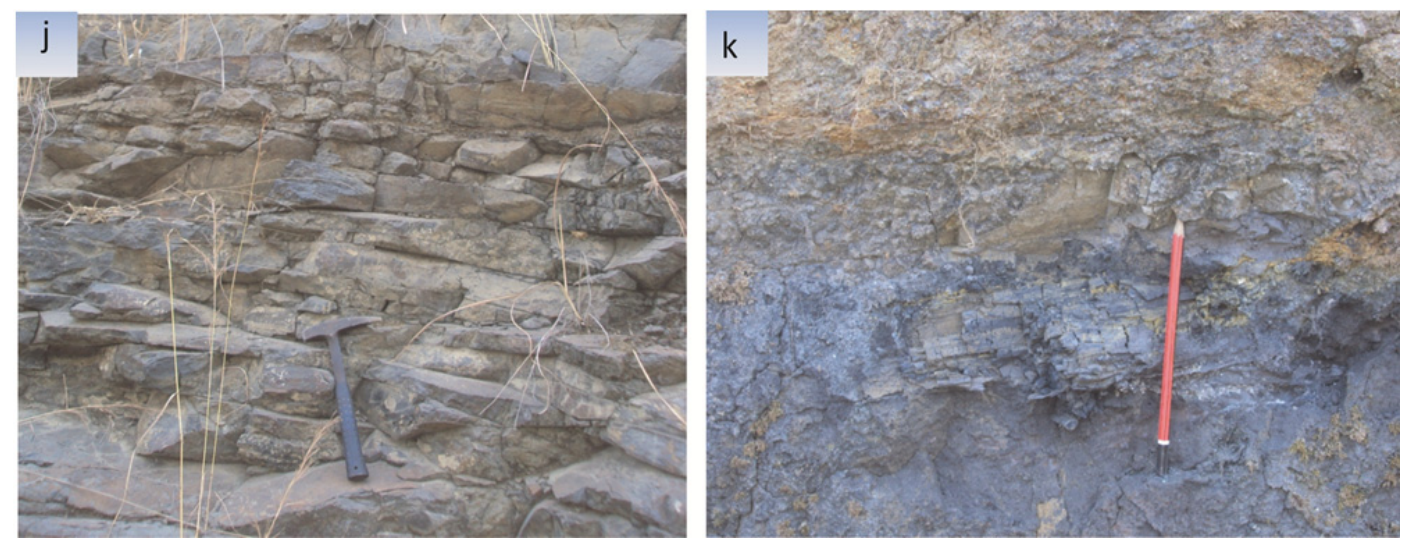

Figure 3. Field photographs of significant physical volcanology aspects of the Baossi-Warack monogenetic cones. (a) Warack monogenetic cone with asymmetrical rim. (b) Symmetrical cone of basaltic lava at the Baossi 1 sampling site. (c) Unbreached symmetrical Baossi 2 monogenetic cone. (d) Blocky columnar basaltic lava flow on the flank of the Warack cone depicted at Warack monogenetic cone. (e) Close up view of columnar basaltic lava flow at Baossi 1 monogenetic cone. (f) Columnar joints on lava flows from the Baossi 2 monogenetic cone. Note the morphological similarity between lava flows at all these monogenetic edifices. (g) Lava flow exposed along roadcut with the boundary of two successive flows discernable. Both flows have similar textural characteristics and are not separated by a weathering boundary. (h) Tephra sequence beneath the flows in Figure 3 (g). Note the regular layering and the absence of a paleosoil between the layers. (i) Close up view of columnar jointing in top layer of lava flow shown in Figure 3 (g). (j) Close up view of lava flow with near horizontal joints at the base of the lava flow depicted in Figure $3(\mathrm{~g})$. (k) Charred wood at the base of the pencil within the tephra sequence shown in Figure 3 (h)

Under the microscope the lavas are distinctly porphyritic and the mineral assemblage is dominated by olivine phenocryts $(5-8 \%)$, clinopyroxene phenocrysts $(\sim 5 \%)$ while plagioclase occurs mainly as microphenocrysts $(\sim 10 \%)$ in a glassy groundmass $(\sim 77-80 \%)$. Vesicles are not very common. Olivine and clinopyroxene microlites also occur together with chrome spinel and titanomagnetite in the matrix. Flow banding is weak in most samples and it is defined by aligned plagioclase microlites (Figure 4a). Two olivine populations are recognized. The first group (olivine 1) comprises crystals that have resorbed margins with plagioclase inclusions at the rims (Figure 4b). Such olivine may also be glomerocrystic to xenocrystic occurring together with titanomagnetite, spinel and clinopyroxene (Figure 4c) and usually anhedral in form. Group 1 olivine relics also occur as inclusions in subhedral titanomagnetite microphenocrysts (Figure 4d). The second population of olivine grains (olivine 2) often appears skeletal (Figure 4e) due to rapid growth. Most of the olivine 2 phenocrysts are euhedral with titanomagnetite and chrome spinel inclusions and subhedral titanomagnetite corona around them (Figure 4f). These grains are pristine and zoned with continuous thin rims around a much wider core. Similar to olivine, two clinopyroxene populations are also discernible. The early clinopyroxene (clinopyroxene 1) grains are often zoned with porous, resorbed and sieve-textured cores (Figure 4g) and the boundary between the core and the rim is irregular. Often it forms glomerocrysts with dismembered and significantly resorbed fragments (Figure 4h). The second group of clinopyroxene (clinopyroxene 2) comprises euhedral to subhedral grains with distinct rhythmic, sector and hour glass zoning (Figure 4i). Usually these grains enclose euhedral olivine 2 crystals (Figure 4j) reflecting the sequence of crystallisation of these phases. Plagioclase laths have sector twinning and swallow tail shape due to rapid growth (Figure 4k). They occur as inclusions sometimes and often inter-grown with clinopyroxene (Figure 41). 

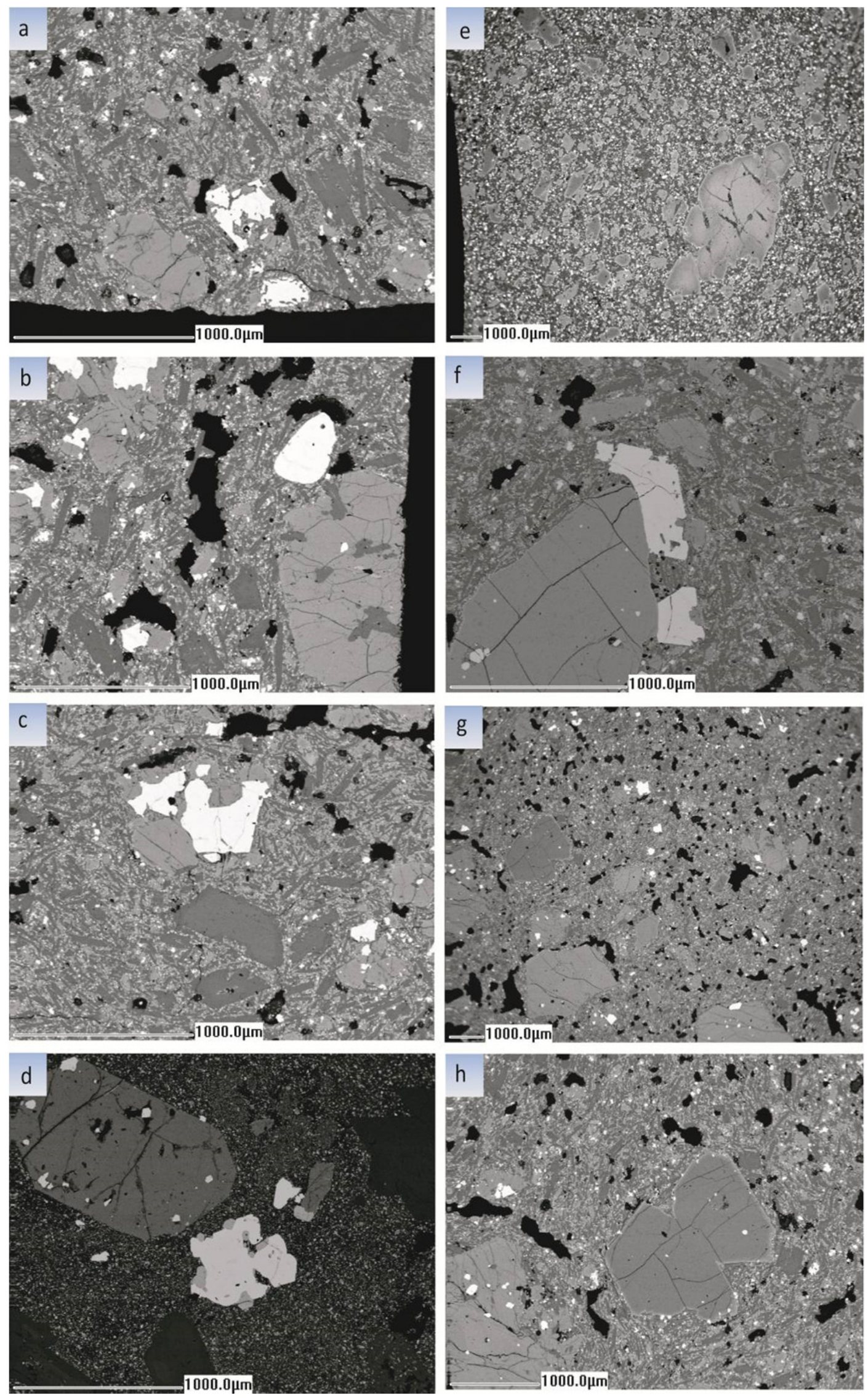

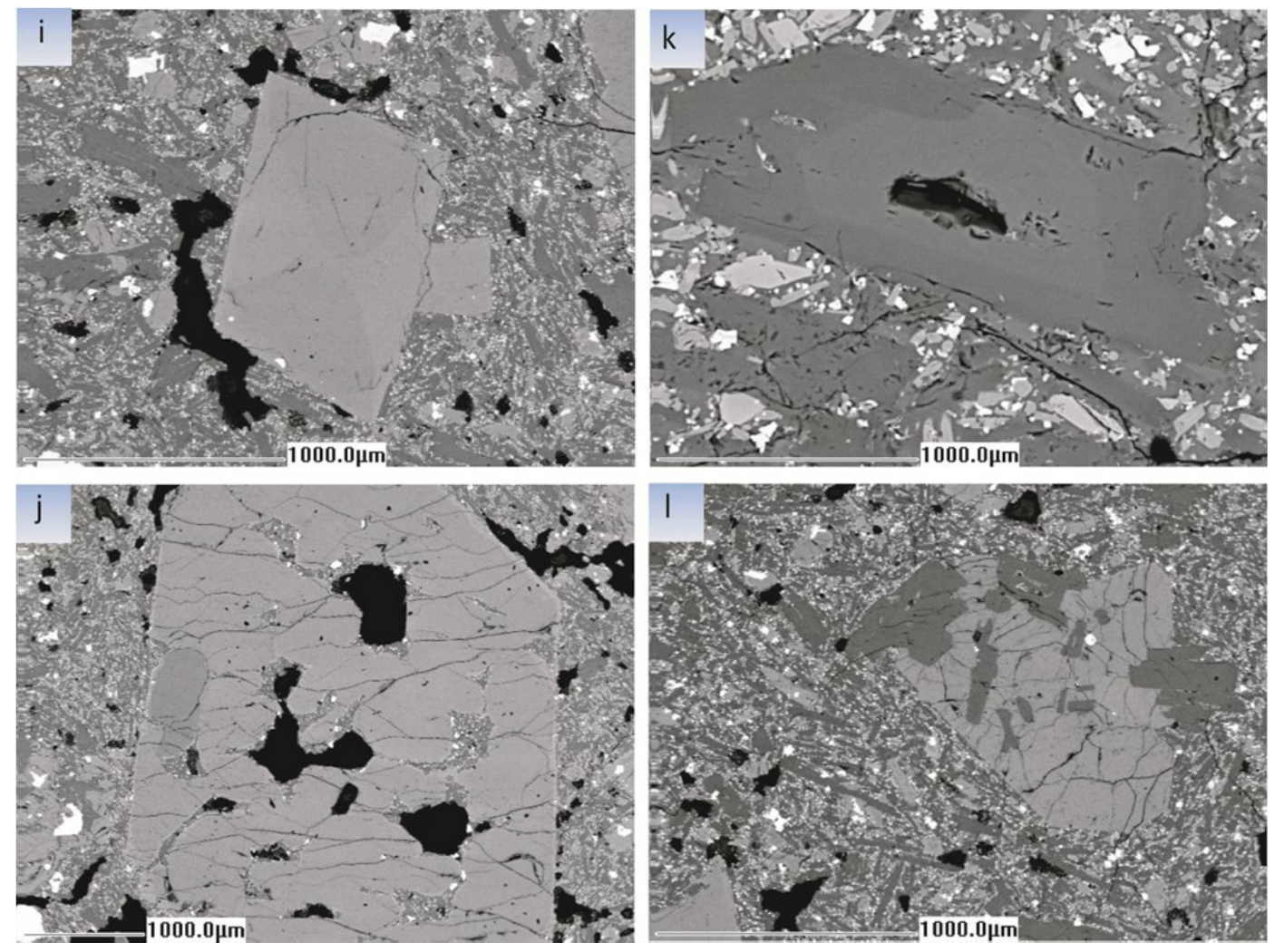

Figure 4. Petrographic characteristics of the lava flows from the monogenetic cones investigated in this study. All the images are secondary electron backscattered (BSE) images. (a) Laths of elongated plagioclase microlites (grey) defining flow banding in the lava flows. (b) Large olivine 1 crystal (light grey, bottom right) with plagioclase inclusions at the rim. (c) Olivine 1 crystals (light grey) intergrown with titanomagnetite (white). Note anhedral nature of the olivine grains in this glomerocryst. (d) Titanomagnetite crystal (white) with group 1 olivine grains as inclusions (grey). To the left is an euhedral clinopyroxene 2 crystal. (e) Skeletal olivine 2 crystals (grey) most with thin rims around a more elaborate core. (f) Euhedral undeformed olivine 2 phenocryst (grey, bottom left) with tiny spinel inclusions (light grey) and surrounded by euhedral titanomagnetite phenocrysts (white). (g) Clinopyroxene 1 crystals (grey, centre left) with light coloured spinel inclusions. Note the fragmented nature of these grains. (h) Enlarged view of figure 4 (g) highligting the resorbed nature of the clinopyroxene 1 grain (bottom left, grey) in contrast to the euhedral and twinned olivine 2 grains (centre of image, darker grey). (i) Euhedral clinopyroxene 2 grain (light grey, centre) with distinct hour glass sector zoning. (j) Euhedral clinopyroxene 2 grain enclosing olivine microphenocryst (light grey inclusion to the left) suggesting that olivine crystallized first. (k) Zoned swallow tail plagioclase grain (grey with dark core) reflecting rapid crystal growth. (l) Clinopyroxene crystals (dark grey) intergrown with plagioclase laths (light grey) in a microlite-rich matrix

The range of compositions represented by olivine and clinopyroxene in the lavas is provided in table 1 . Interestingly the two olivine and clinopyroxene populations are indistinguishable in terms of their mineral chemistry. The forsterite content of the olivine ranges from 75 to 78 with the core slightly more forsteritic. Molar ratios of Fe:Mg:Ca define augite composition for the clinopyroxenes (Table 1). The liquidus temperatures calculated for the olivine-clinopyroxene pairs (Table 1) define a very narrow range $\left(1040-1156^{\circ} \mathrm{C}\right)$.

Table 1. Olivine-clionpyroxene pairs for Baossi lava flows used in calculating liquidus temperature $\left(\mathrm{T}^{\circ} \mathrm{C}\right)$ based on the method of Loucks (1996)

\begin{tabular}{lcccccccccc}
\hline Sample & BA21 & BA21 & BA21 & BA21 & BA21 & BA21 & BA21 & BA21 & BA21 & BA21 \\
\hline Olivine (Ol) & & & & & & & & & & \\
No. & O1-01 & O1-02 & Ol-03 & Ol-04 & O1-05 & O1-06 & O1-07 & O1-08 & O1-09 & O1-10 \\
Paired with & Cpx-01 & Cpx-02 & Cpx-03 & Cpx-04 & Cpx-05 & Cpx-06 & Cpx-07 & Cpx-08 & Cpx-09 & Cpx-10 \\
\hline
\end{tabular}




\begin{tabular}{|c|c|c|c|c|c|c|c|c|c|c|}
\hline $\mathrm{SiO}_{2}$ & 38.86 & 38.80 & 38.87 & 39.01 & 38.84 & 38.85 & 38.88 & 38.79 & 39.11 & 38.99 \\
\hline $\mathrm{Cr}_{2} \mathrm{O}_{3}$ & 0.01 & 0.01 & 0.01 & 0.01 & 0.01 & 0.01 & 0.01 & 0.01 & 0.01 & 0.01 \\
\hline $\mathrm{FeO}$ & 21.95 & 20.14 & 20.95 & 21.95 & 21.96 & 21.97 & 21.89 & 21.99 & 21.97 & 21.97 \\
\hline $\mathrm{MnO}$ & 0.38 & 0.33 & 0.38 & 0.38 & 0.38 & 0.38 & 0.38 & 0.38 & 0.38 & 0.38 \\
\hline $\mathrm{MgO}$ & 37.85 & 40.53 & 38.85 & 37.87 & 37.85 & 37.88 & 38.01 & 37.82 & 37.79 & 37.88 \\
\hline $\mathrm{NiO}$ & 0.04 & 0.13 & 0.04 & 0.04 & 0.04 & 0.04 & 0.04 & 0.04 & 0.04 & 0.04 \\
\hline $\mathrm{CaO}$ & 0.23 & 0.17 & 0.23 & 0.23 & 0.23 & 0.23 & 0.23 & 0.23 & 0.23 & 0.23 \\
\hline Total & 99.33 & 100.12 & 99.34 & 99.50 & 99.32 & 99.37 & 99.45 & 99.27 & 99.54 & 99.52 \\
\hline $\mathrm{Mg} \#$ & 75.45 & 78.20 & 76.77 & 75.46 & 75.44 & 75.45 & 75.58 & 75.40 & 75.41 & 75.45 \\
\hline \multicolumn{11}{|c|}{ Clinopyroxene (Cpx) } \\
\hline & Cpx-01 & Cpx-02 & Cpx-03 & Сpx-04 & Cpx-05 & Cpx-06 & Cpx-07 & Cpx-08 & Сpx-09 & Cpx-10 \\
\hline Paired with & Ol-01 & Ol-02 & Ol-03 & Ol-04 & Ol-05 & Ol-06 & Ol-07 & Ol-08 & Ol-09 & Ol-10 \\
\hline $\mathrm{SiO}_{2}$ & 50.66 & 52.37 & 51.66 & 50.67 & 51.59 & 52.00 & 51.01 & 50.68 & 50.68 & 51.01 \\
\hline $\mathrm{TiO}_{2}$ & 0.58 & 0.35 & 0.58 & 0.58 & 0.57 & 0.58 & 0.58 & 0.55 & 0.59 & 0.58 \\
\hline $\mathrm{Al}_{2} \mathrm{O}_{3}$ & 3.34 & 3.63 & 3.34 & 3.33 & 3.36 & 3.30 & 3.34 & 3.33 & 3.34 & 3.34 \\
\hline $\mathrm{Cr}_{2} \mathrm{O}_{3}$ & 0.44 & 0.39 & 0.44 & 0.44 & 0.45 & 0.44 & 0.44 & 0.44 & 0.44 & 0.44 \\
\hline $\mathrm{FeO}$ & 7.22 & 4.73 & 7.22 & 7.20 & 7.21 & 7.21 & 7.21 & 7.22 & 7.21 & 7.22 \\
\hline $\mathrm{MnO}$ & 0.21 & 0.16 & 0.21 & 0.21 & 0.21 & 0.21 & 0.21 & 0.21 & 0.21 & 0.21 \\
\hline $\mathrm{MgO}$ & 15.37 & 16.28 & 15.35 & 15.39 & 15.36 & 15.34 & 15.37 & 15.39 & 15.38 & 15.38 \\
\hline $\mathrm{NiO}$ & 0.03 & 0.04 & 0.03 & 0.03 & 0.03 & 0.03 & 0.03 & 0.03 & 0.03 & 0.03 \\
\hline $\mathrm{CaO}$ & 21.13 & 22.55 & 21.14 & 21.14 & 21.02 & 21.01 & 21.13 & 21.14 & 21.13 & 21.13 \\
\hline $\mathrm{Na}_{2} \mathrm{O}$ & 0.29 & 0.22 & 0.29 & 0.29 & 0.29 & 0.28 & 0.23 & 0.29 & 0.29 & 0.29 \\
\hline $\mathrm{K}_{2} \mathrm{O}$ & 0.02 & 0.02 & 0.02 & 0.02 & 0.02 & 0.02 & 0.02 & 0.02 & 0.02 & 0.02 \\
\hline Total & 99.28 & 100.74 & 100.27 & 99.30 & 100.11 & 100.42 & 99.56 & 99.30 & 99.32 & 99.64 \\
\hline $\mathrm{X}_{\mathrm{Fe}}$ & 11.71 & 7.54 & 11.71 & 11.71 & 11.71 & 11.71 & 11.71 & 11.71 & 11.71 & 11.71 \\
\hline $\mathrm{X}_{\mathrm{Mg}}$ & 44.42 & 46.33 & 44.42 & 44.42 & 44.42 & 44.42 & 44.42 & 44.42 & 44.42 & 44.42 \\
\hline $\mathrm{X}_{\mathrm{Ca}}$ & 43.88 & 46.13 & 43.88 & 43.88 & 43.88 & 43.88 & 43.88 & 43.88 & 43.88 & 43.88 \\
\hline Total & 100.00 & 100.00 & 100.00 & 100.00 & 100.00 & 100.00 & 100.00 & 100.00 & 100.00 & 100.00 \\
\hline $\mathrm{T}\left({ }^{\circ} \mathrm{C}\right)$ & 1082.4 & 1040.1 & 1150.8 & 1080.3 & 1135.4 & 1156.1 & 1114.4 & 1079.5 & 1081.9 & 1099.9 \\
\hline Sample & WA10 & WA10 & WA10 & WA10 & WA10 & WA10 & WA10 & WA10 & WA10 & WA10 \\
\hline \multicolumn{11}{|l|}{ Olivine (Ol) } \\
\hline & Ol-11 & Ol-12 & Ol-13 & Ol-14 & Ol-15 & Ol-16 & Ol-17 & Ol-18 & Ol-19 & Ol-20 \\
\hline Paired with & Cpx-11 & Cpx-12 & Cpx-13 & Cpx-14 & Cpx-15 & Сpx-16 & Cpx-17 & Cpx-18 & Cpx-19 & Cpx-20 \\
\hline$\overline{\mathrm{SiO}_{2}}$ & 39.86 & 38.83 & 38.87 & 38.85 & 38.79 & 38.84 & 38.88 & 38.87 & 38.89 & 38.84 \\
\hline $\mathrm{Cr}_{2} \mathrm{O}_{3}$ & 0.01 & 0.01 & 0.01 & 0.01 & 0.01 & 0.01 & 0.01 & 0.01 & 0.01 & 0.01 \\
\hline $\mathrm{FeO}$ & 20.99 & 21.95 & 21.99 & 21.95 & 21.89 & 21.92 & 21.95 & 21.96 & 21.95 & 21.91 \\
\hline $\mathrm{MnO}$ & 0.38 & 0.38 & 0.38 & 0.38 & 0.38 & 0.38 & 0.39 & 0.38 & 0.38 & 0.38 \\
\hline $\mathrm{MgO}$ & 37.85 & 37.84 & 37.84 & 37.82 & 38.81 & 37.84 & 37.83 & 37.82 & 37.83 & 37.89 \\
\hline $\mathrm{NiO}$ & 0.04 & 0.04 & 0.04 & 0.04 & 0.04 & 0.04 & 0.04 & 0.04 & 0.04 & 0.04 \\
\hline $\mathrm{CaO}$ & 0.23 & 0.23 & 0.23 & 0.22 & 0.22 & 0.24 & 0.24 & 0.23 & 0.24 & 0.23 \\
\hline Total & 99.37 & 99.29 & 99.37 & 99.28 & 100.15 & 99.28 & 99.35 & 99.32 & 99.35 & 99.31 \\
\hline $\mathrm{Mg \#}$ & 76.27 & 75.45 & 75.41 & 75.44 & 75.96 & 75.48 & 75.44 & 75.43 & 75.44 & 75.51 \\
\hline \multicolumn{11}{|c|}{ Clinopyroxene (Cpx) } \\
\hline No. Cpx & Cpx-11 & Cpx-12 & Cpx-13 & Cpx-14 & Cpx-15 & Cpx-16 & Cpx-17 & Cpx-18 & Cpx-19 & Cpx-20 \\
\hline Paired with & Ol-11 & $\mathrm{Ol}-12$ & Ol-13 & Ol-14 & Ol-15 & Ol-16 & Ol-17 & Ol-18 & Ol-19 & Ol-20 \\
\hline $\mathrm{SiO}_{2}$ & 51.02 & 51.05 & 50.91 & 51.11 & 50.99 & 51.23 & 51.04 & 50.67 & 50.69 & 51.01 \\
\hline $\mathrm{TiO}_{2}$ & 0.59 & 0.58 & 0.59 & 0.58 & 0.57 & 0.58 & 0.58 & 0.56 & 0.58 & 0.58 \\
\hline $\mathrm{Al}_{2} \mathrm{O}_{3}$ & 3.34 & 3.34 & 3.33 & 3.34 & 3.33 & 3.32 & 3.33 & 3.34 & 3.34 & 3.33 \\
\hline $\mathrm{Cr}_{2} \mathrm{O}_{3}$ & 0.44 & 0.44 & 0.44 & 0.43 & 0.45 & 0.44 & 0.44 & 0.44 & 0.44 & 0.43 \\
\hline $\mathrm{FeO}$ & 7.21 & 7.22 & 7.21 & 7.22 & 7.21 & 7.22 & 7.21 & 7.21 & 7.22 & 7.21 \\
\hline $\mathrm{MnO}$ & 0.21 & 0.21 & 0.21 & 0.21 & 0.21 & 0.21 & 0.21 & 0.21 & 0.21 & 0.21 \\
\hline $\mathrm{MgO}$ & 15.38 & 15.39 & 15.37 & 15.39 & 15.37 & 15.34 & 15.34 & 15.29 & 15.37 & 15.34 \\
\hline $\mathrm{NiO}$ & 0.03 & 0.03 & 0.03 & 0.03 & 0.03 & 0.03 & 0.03 & 0.03 & 0.03 & 0.03 \\
\hline $\mathrm{CaO}$ & 21.13 & 21.23 & 21.13 & 21.14 & 21.13 & 21.13 & 21.13 & 21.12 & 21.13 & 21.12 \\
\hline $\mathrm{Na}_{2} \mathrm{O}$ & 0.29 & 0.29 & 0.29 & 0.29 & 0.29 & 0.29 & 0.29 & 0.29 & 0.29 & 0.29 \\
\hline
\end{tabular}




\begin{tabular}{lcccccccccc}
$\mathrm{K}_{2} \mathrm{O}$ & 0.02 & 0.02 & 0.02 & 0.02 & 0.02 & 0.02 & 0.02 & 0.02 & 0.02 & 0.02 \\
$\mathrm{Total}$ & 99.65 & 99.79 & 99.54 & 99.76 & 99.60 & 99.80 & 99.61 & 99.18 & 99.31 & 99.58 \\
$\mathrm{X}_{\mathrm{Fe}}$ & 11.71 & 11.71 & 11.71 & 11.71 & 11.71 & 11.71 & 11.71 & 11.71 & 11.71 & 11.71 \\
$\mathrm{X}_{\mathrm{Mg}}$ & 44.42 & 44.42 & 44.42 & 44.42 & 44.42 & 44.42 & 44.42 & 44.42 & 44.42 & 44.42 \\
$\mathrm{X}_{\mathrm{Ca}}$ & 43.88 & 43.88 & 43.88 & 43.88 & 43.88 & 43.88 & 43.88 & 43.88 & 43.88 & 43.88 \\
$\mathrm{Total}$ & 100.00 & 100.00 & 100.00 & 100.00 & 100.00 & 100.00 & 100.00 & 100.00 & 100.00 & 100.00 \\
$\mathrm{~T}\left({ }^{\circ} \mathrm{C}\right)$ & 1112.1 & 1095.6 & 1095.6 & 1103.5 & 1106.5 & 1115.1 & 1105.4 & 1090.1 & 1084.1 & 1104.9 \\
\hline
\end{tabular}

Reconnaissance whole rock geochemical data for these flows are presented in Table 2. The lavas are typical alkali basalt to basanite (Figure 5). The basanite has 40.42 to $47.59 \mathrm{wt} \% \mathrm{SiO}_{2}$. This is not matched by a corresponding increase in $\mathrm{K}_{2} \mathrm{O}$ and $\mathrm{P}_{2} \mathrm{O}_{5}$ levels thereby ruling out crustal contamination as the cause for elevated silica in some samples. The $\mathrm{SiO}_{2}$ concentrations therefore represent the pristine composition of the lavas reflecting a magma with pockets at slightly different stages of fractionation.

Table 2. Representative major and trace elements data for the Baossi lava flows and dolerite dykes in the Adamawa plateau

\begin{tabular}{|c|c|c|c|c|c|c|}
\hline \multirow[b]{2}{*}{ Samples code: } & \multicolumn{4}{|c|}{ Lava flows } & \multicolumn{2}{|c|}{ Dolerites } \\
\hline & PK10 & WA10 & BA21 & BA14 & BA25 & BA29 \\
\hline \multicolumn{7}{|c|}{ Major Elements (wt.\%) } \\
\hline $\mathrm{SiO}_{2}$ & 42.80 & 47.59 & 40.42 & 40.65 & 48.88 & 46.69 \\
\hline $\mathrm{Al}_{2} \mathrm{O}_{3}$ & 13.69 & 14.41 & 12.42 & 12.77 & 16.04 & 16.01 \\
\hline $\mathrm{Fe}_{2} \mathrm{O}_{3}$ & 11.98 & 10.72 & 14.78 & 14.22 & 10.98 & 11.06 \\
\hline $\mathrm{MnO}$ & 0.18 & 0.16 & 0.24 & 0.24 & 0.17 & 0.16 \\
\hline $\mathrm{MgO}$ & 7.61 & 9.13 & 7.76 & 7.15 & 4.87 & 5.27 \\
\hline $\mathrm{CaO}$ & 9.78 & 9.04 & 10.72 & 10.30 & 7.24 & 6.84 \\
\hline $\mathrm{Na}_{2} \mathrm{O}$ & 3.28 & 2.89 & 3.83 & 4.34 & 3.05 & 2.77 \\
\hline $\mathrm{K}_{2} \mathrm{O}$ & 1.31 & 1.79 & 2.08 & 2.25 & 1.83 & 1.32 \\
\hline $\mathrm{TiO}_{2}$ & 2.91 & 2.45 & 3.25 & 3.14 & 2.11 & 2.17 \\
\hline $\mathrm{P}_{2} \mathrm{O}_{5}$ & 1.13 & 0.57 & 1.43 & 1.40 & 0.54 & 0.54 \\
\hline $\mathrm{SO}_{3}$ & 0.00 & 0.00 & 0.06 & 0.05 & 0.16 & 0.19 \\
\hline L.O.I & 4.69 & 1.15 & 2.46 & 2.85 & 3.96 & 6.81 \\
\hline Total & 99.36 & 99.90 & 99.45 & 99.36 & 99.83 & 99.83 \\
\hline \multicolumn{7}{|c|}{ Trace Elements (ppm) } \\
\hline $\mathrm{Ba}$ & 941 & 622 & 1004 & 1039 & 713 & 965 \\
\hline $\mathrm{Ce}$ & 167 & 102 & 226 & 235 & 92 & 59 \\
\hline Co & 39 & 42 & 44 & 41 & 35 & 37 \\
\hline $\mathrm{Cr}$ & 195 & 340 & 116 & 104 & 26 & 20 \\
\hline $\mathrm{Cu}$ & 34 & 56 & 54 & 58 & 39 & 50 \\
\hline $\mathrm{Ga}$ & 27 & 20 & 32 & 36 & 27 & 26 \\
\hline $\mathrm{La}$ & 93 & 65 & 122 & 143 & 47 & 44 \\
\hline $\mathrm{Nb}$ & 98 & 54 & 134 & 143 & 22 & 18 \\
\hline $\mathrm{Nd}$ & 67 & 43 & 78 & 77 & 38 & 28 \\
\hline $\mathrm{Ni}$ & 177 & 209 & 102 & 89 & 45 & 47 \\
\hline $\mathrm{Pb}$ & 9 & 7 & 11 & 2 & 8 & 11 \\
\hline $\mathrm{Rb}$ & 48 & 41 & 50 & 56 & 73 & 50 \\
\hline $\mathrm{Sc}$ & 21 & 25 & 25 & 25 & 24 & 24 \\
\hline $\mathrm{Sr}$ & 1223 & 751 & 1391 & 1471 & 748 & 762 \\
\hline Th & 9 & 1 & 9 & 17 & 5 & 0 \\
\hline $\mathrm{U}$ & 0 & 0 & 4 & 5 & 2 & 0 \\
\hline V & 213 & 200 & 229 & 225 & 169 & 179 \\
\hline Y & 28 & 26 & 37 & 39 & 44 & 36 \\
\hline $\mathrm{Zn}$ & 113 & 92 & 142 & 149 & 101 & 92 \\
\hline $\mathrm{Zr}$ & 343 & 257 & 435 & 447 & 355 & 272 \\
\hline
\end{tabular}




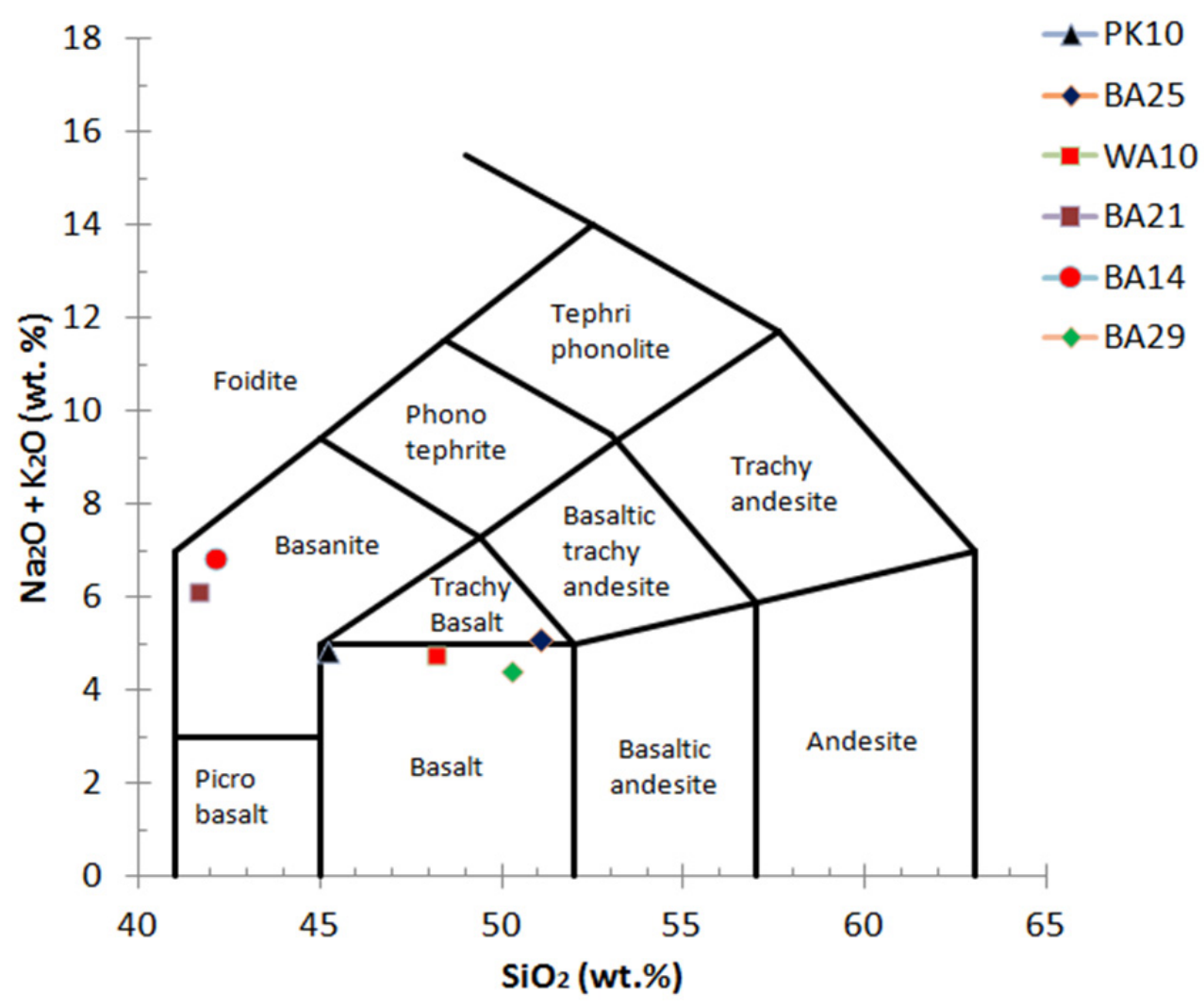

Figure 5. Classification of representative lava flows and dolerite dykes from Baossi area (after Le Bas et al., 1986)

\section{Discussion}

The cones of the Baossi field are small with very restricted volumes of basaltic flows. This is a typical feature of several monogenetic cones the world over. Although the flows at such cones are small in volume they may record systematic variations in composition (Strong \& Wolff, 2003; Needham et al., 2011; Brenna et al., 2012; Sakuyama et al., 2009), texture (Boyce et al., 2015; Luhr, 2001; Sohn et al., 2012) and eruption style (Brenna et al., 2010) reflecting complex subterranean magma mixing and mingling processes at work in such magmatic plumbing systems. The basaltic flows of the Baossi cones are inter-layered with thin tephra bands. However, no weathering surfaces exist neither between the lava flows nor between the lava flows and these pyroclastic horizons. There was therefore no significant time break between the eruption of these different materials. This confirms that the cones are monogenetic in origin yet in the course of the eruption the activity waxed and waned resulting in oscillations in the eruption dynamics between explosive Strombolian activity (producing tephra) and more quiescent Hawaiian type lava effusion.

The textural features of the lava samples investigated provide useful clues to the internal workings of this monogenetic eruption. The olivine 1 and clinopyroxene 1 crystal populations and the glomerocrysts represent an early crystal mush that was residing within a partly fractionated magma in a sub-crustal chamber. This mush probably had degassed and became too viscous to erupt. The introduction of a new magma batch into the chamber resulted in the resorption of the mush crystals and the crystallization of pristine and euhedral olivine 2 and clinopyroxene 2 crystals. This interpretation is also supported by the presence of plagioclase laths in dismembered clinopyroxene fragments and the development of uninterrupted thin rims around olivine and clinopyroxene phenocrysts. A similar textural feature had been observed by Suh et al. (2003) from samples of the 1999 eruption of Mt Cameroon along the CVL; an eruption that produced both hawaiite and basanite lava due also to the interaction of separate magma batches within the chamber. Also Nemeth et al. (2003) identified polymagmatic fractionation and mixing processes in the monogenetic Waipiata Volcanic field, New Zealand. These authors noted that early-formed basaltic magma stalled in the chamber and the eruption was eventually initiated when ascending pristine basanitic magma flushed out the fractionated melt. We envisage similar mechanisms at work at the Baossi monogentic cones backed by the textural arguments presented above. This is a significant contribution as it demonstrates that along the CVL complex magma plumbing systems are not 
restricted to the polygenetic and more massive edifices but can be expected at monogenetic mounds.

At Baossi the heat from the fresh magma batch was sufficient to homogenize the liquidus temperature within the chamber resulting in the narrow range of temperature determined by the Loucks (1996) geothermometer regardless of the olivine-clinopyroxene pair analyzed. This emphasizes the suitability of this geothermometer as noted by Diogo et al. (2006) and Trevor et al. (2007) at different basaltic systems. However, subtle differences can be discerned from the preliminary geochemical data presented in this study to support the concept of magma interaction in small reservoirs beneath the cones. The difference between the highest and lowest $\mathrm{SiO}_{2}$ concentrations in the lava samples is $\sim 7 \mathrm{wt} \%$. However, silica enrichment is not accompanied by simultaneous increases in the total alkali content (Table 2). Also olivine fractionation alone would lead to a systematic decrease in $\mathrm{MgO}$ as $\mathrm{SiO}_{2}$ content increases. This is also not the case as the lava sample with high silica content also has the highest $\mathrm{MgO}$ concentration (Table 2). Resolving these contradictory observations requires a mechanism wherein successive magma pulses have mixed yet relics of the fractionated melt richer in silica survived. We therefore conclude that the eruption at Baossi was triggered and sustained by the supply of a fresh pulse of magma into a reservoir containing a partly fractionated, partly crystallized and more evolved residual melt and crystal mush.

\section{Acknowledgments}

This contribution is part of the PhD thesis of Anicet Feudjio Tiabou underway at the University of Yaounde 1. Professor Cheo Emmanuel Suh was involved in discussions on this work at various stages of development including support with the EMPA work and he improved significantly on the language of the final text. We acknowledge the timely and meticulous review by an anonymous journal reviewer that improved on the clarity of the text.

\section{References}

Aka, F. T., Ngako, K., Kusakabe, M., Sumino, H., Tanyileke, G., Ateba, B., \& Hell, J. (2004). Symmetrical helium isotope distribution on the Cameroon volcanic line, West Africa. Chemical Geology, 203, 205-223.

Brenna, M., Cronin, S. J., Smith, I. E. M., Sohn, Y. K., \& Nemeth, K. (2010). Mechanism driving polymagmatic activity at a monogenetic volcano, Udo, Jeju Island, South Korea. Contributions to Mineralogy and Petrology, 160, 931-950.

Brenna, M., Cronin, S. J., Hemeth, K., Smith, I. E. M., \& Sohn, Y. (2011). The influence of magma plumbing complexity on monogenetic eruptions, Jeju Island, Korea. Terra Nova, 23, 70-75.

Brenna, M., Cronin, S. J., Smith, I. E. M., Maas, R., \& Sohn, Y. K. (2012). How small-volume basaltic magmatic systems develop: A case study from the Jeju Island Volcanic field, Korea. Journal of Petrology, 53, 985-1018.

Boyce, J. A., Nicholls, I. A., Keays, R. R., \& Hayman, P. C. (2015). Variation in parental magmas of Mt. Rouse, a complex polymagmatic monogenetic volcano in the basaltic intraplate Newer Volcanics Province, southeast Australia. Contributions to Mineralogy and Petrology. http://dx.doi.org/10.1007/s00410-015-1106-y

Déruelle, B., Ngounouno, I., \& Demaiffe, D. (2007). The Cameroon Hot Line (CHL): a unique example of active alkaline intraplate structure in both oceanic and continental lithospheres. Comptes Rendus Géoscience, 339, 589-598.

Diogo, R. N. R., Inverno, C. M. C., Oliveira, V. M. J., \& Rosa, C. J. P. (2006). Geochemistry and geothermometry of volcanic rocks from Serra Branca, Iberian Pyrite Belt, Portugal. Gondwana Research, 10 (3-4), 328-339.

Grant, N. K., Rex, D. C., \& Feeth, S. J. (1972). Potassium-argon ages and strontium isotope ratio measurements from volcanic rocks in northeastern Nigeria. Contributions to Mineralogy and Petrology, 35, 277-292.

Kamgang, P., Njonfang, E., Chazot, G., \& Tchoua, F. (2007). Geochimie et geochronologie des laves felsiques des monts Bamenda (ligne volcanique du Cameroun). Comptes Rendus Geoscience, 339, 659-666.

Le Bas, M. J., Le Maitre, R. W., Streckeisen, A., \& Zanettin, B. (1986). A chemical classification of volcanic rocks based on the total alkali-silica diagram. Journal of Petrology, 27, 745-750.

Loucks, R. R. (1996). A precise olivine-augite Mg-Fe-exchange gerthermometer. Contributions to Mineralogy and Petrology, 125, 140-150.

Luhr, J. F. (2001). Glass inclusions and melt volatile contents at Paricutin volcano, Mexico. Contributions to Mineralogy and Petrology, 142, 261-283. 
Marzoli, A., Renne, P. R., Picirillo, E. M., Francesca, C., Bellieni, G., Melfi, A. J., Nyobe, J. B., \& N'ni, J. (1999). Silisic magmas from the continental Cameroon Volcanic Line (Oku, Bambouto and Ngaoundere): ${ }^{40} \mathrm{Ar}-{ }^{39} \mathrm{Ar}$ dates, petrology, Sr-Nd-O isotopes and their petrogenetic significance. Contributions to Mineralogy and Petrology, 135, 133-150.

Milelli, L., Fourel, L., \& Jaupart, C. (2011). A lithospheric instability origin for the Cameroon Volcanic Line. Earth and Planetary Sience Letters, 335-336, 80-87.

Montigny, R., Ngounouno, I., \& Déruelle, B. (2004). K-Ar ages of magmatic rocks from the Garoua rift: their place in the frame of the "Cameroun Line". Comptes Rendus Academie des Sciences Paris, 336, 1463-1471.

Needham, A. J., Lindsay, J. M., Smith, I. E. M., Augustinus, P., \& Shane, P. A. (2011). Sequential eruption of alkaline and sub-alkaline magmas from a small monogenetic volcano in the Auckland volcanic field, New Zealand. Journal of Volcanology and Geothermal Research, 201, 126-142.

Nemeth, K., White, J. D. L., Reay, A., \& Martin, U. (2003). Compositional variation during monogenetic volcano growth and its implications for magma supply to continental volcanic fields. Journal of the Geological Society of London, 160, 523-530.

Ngwa, C. N. (2010). Phreatomagmatic activity at Debundscha maar: Tephra sequence, melt inclusions and bulk rock geochemistry (Unpublished doctoral dissertation). University of Buea, Cameroon.

Nkouandou O. F., Ngounouno, I., Déruelle, B., Ohnenstetter, D., Montigny, R., \& Demaiffe, D. (2008). Petrology of the Mio-Pliocene volcanism to the North and East of Ngaoundéré (Adamawa, Cameroon). Comptes Rendus Géoscience, 340, 28-37.

Nkouandou, O. F., \& Temdjim, R. (2011). Petrology of spinel lherzolite xenoliths and host basaltic lava from Ngao Voglar volcano, Adamawa Massif (Cameroon Volcanic Line, West Africa): Equilibrium conditions and mantle characteristics. Journal of Geosciences, 56, 375-387.

Rankenburg, K., Lassiter, J., \& Brey, G. (2005). The role of continental crust and lithospheric mantle in the genesis of Cameroon volcanic line lavas: constraints from isotopic variations in lavas and megacrysts from the Biu and Jos Plateaux. Journal of Petrology, 46, 169-190.

Reusch, A. M., Nyblade, A. A., Tibi, R., Wiens, D. A., Shore, P. J., Bekoa, A., .. Nnange, J. M. (2011). Mantle transition zonr thickness beneath Cameroon: evidence for an upper mantle origin for the Cameroon Volcanic Line. Geophysical Journal International, 187, 1146-1150.

Tokam, A. P. K., Tabod, C. T., Nyblade, A. A., Julia, J., Wiens, D. A., \& Pasyanos, M. E. (2010). Structure of the crust beneath Cameroon, West Africa, from the joint inversion of Rayleigh wave group velocities and receiver functions. Geophysical Journal International, 183, 1061-1076.

Sakuyama, T., Ozawa, K., Sumino, H., \& Nagao, K. (2009). Progressive melt extraction from upwelling mantle constrained by the Kita-Matsura basalts in NW Kyushu, SW Japan. Journal of Petrology, 50, 725-779.

Sohn, Y. K., Cronin, J., Brenna, M., Smith, I. E. M., Nemeth, K., White, J. D. L., ... Kwon, C. W. (2012). Ilchulbong tuff cone, Jeju Island, Korea, revisited: A compound monogenetic volcano involving multiple magma pulses, shifting vents, and discrete eruptive phases. Geological Society of America Bulletin, 3-4, 259-274.

Strong, M., \& Wolff, J. (2003). Compositional variations within scoria cones. Geology, 31, 143-146.

Suh, C. E., Sparks, R. S. J., Fitton, J. G., Ayonghe, S. N., Annen, C., Nana, R., \& Luckman, A. (2003). The 1999 and 2000 eruptions of Mount Cameroon: Eruption behaviour and petrochemistry of lava. Bulletin of Volcanology, 65, 267-287.

Suh, C. E., Luhr, J. F., \& Njome, M. S. (2008). Olivine-hosted glass inclusions from Scoriae erupted in 1954-2000 at Mount Cameroon volcano, West Africa. Journal of Volcanology and Geothermal Research, $169,1-33$.

Teitchou, M. I., Gregoire, M., Temdjim, R., Ghogomu, R. T., Ngwa, C. N., \& Aka, F. T. (2011). Mineralogical and geochemical fingerprints of mantle metasomatism beneath Nyos volcano (Cameroon volcanic line). In: Beccaluva, L., Bianchini, G., Wilson, M., (Eds.), Volcanism and evolution of the African Lithosphere. Geological Society of America, 478, 193-210.

Temdjim, R., Kengne, F., \& Nguetkam, J. P. (2003). Les risques volcaniques associés à l'activité magmatique récente sur le plateau de l'Adamaoua (Nord-Cameroun), Ligne du Cameroun. Revue de Géographie du Cameroun, $\mathrm{XV}, \mathrm{n}^{\circ} 1,68-77$. 
Temdjim, R., Njilah, I. K., Kamgang, P., \& Nkoumbou, C. (2004). Données nouvelles sur les laves felsiques de Ngaoundéré (Adamaoua, ligne du Cameroun) : chronologie K/Ar et Pétrologie. African Journal of Science and Technology, Science and Engineering Series, 5, $n^{\circ} 2,113-123$.

Temdjim, R., Tchouankoué, J. P., Kamgang, P., \& Tchoua, F. (2006). Sur l'existence d'un maar trachytique dans la ligne volcanique du Cameroun : le maar Mbalang-Djalingo dans la région de Ngaoundéré (Plateau de l’Adamaoua). Revue de Géographie du Cameroun, XVII n¹, 67-71.

Temdjim, R., Wamba, N. D. G., Njilah, I. K., \& Hébert, V. (2010). Kélyphitisation des grenats des pyroxénites du maar basaltique de Youkou, Ngaoundéré-Est (Adamaoua-Cameroun). Annales de la Faculté des Sciences, Université de Yaoundé 1, série Sciences de la Terre, $38 \mathrm{n}^{\circ}$ 1, 1-16.

Trevor, J. F., Leonid, V. D., Alexei, A., David, H. G., \& Clifford, E. F. (2007). The application of olivine geothermometry to infer crystallization temperatures of parental liquids: Implications for the temperature of MORB magmas. Chemical Geology, 241, 207-233.

Walker, G. P. L. (2000). Basaltic volcanoes and volcanic systems. In Sigurdsson, H. (Ed.), Encyclopedia of volcanoes (p. 223). Academic Press, New York.

\section{Copyrights}

Copyright for this article is retained by the author(s), with first publication rights granted to the journal.

This is an open-access article distributed under the terms and conditions of the Creative Commons Attribution license (http://creativecommons.org/licenses/by/3.0/). 